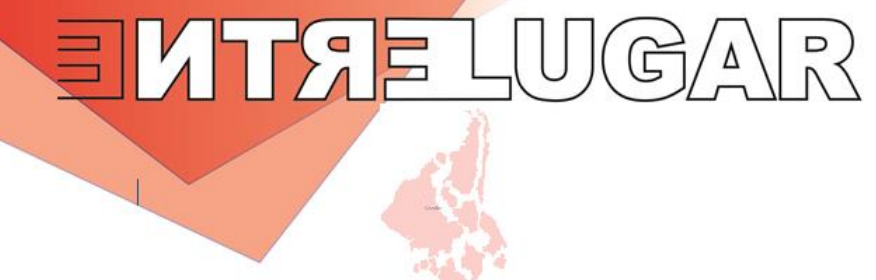

\title{
A COMPETITIVIDADE TERRITORIAL: ALGUNS ELEMENTOS PARA DISCUSSÃO ${ }^{1}$
}

\section{TERRITORIAL COMPETITIVENESS: SOME ELEMENTS FOR DISCUSSION}

\author{
COMPETITIVIDAD TERRITORIAL: ALGUNOS ELEMENTOS PARA \\ DISCUSIÓN
}

\begin{abstract}
Não há no Brasil maior intervencionista do que o liberalista guinado aos postos públicos de decisão.
\end{abstract}

Rangel (2005[1959])

\section{Márcio Rogério Silveira}

Doutor em Geografia pela Unesp - Presidente Prudente. Professor no Departamento de Geociências da Universidade Federal de Santa Catarina (UFSC). Líder do Grupo de Estudos em Desenvolvimento Regional e Infraestruturas (GEDRI), Bolsista de Produtividade em Pesquisa II do CNPq.

marcio.gedri@gmail.com

\section{RESUMO}

A competitividade territorial é o uso de princípios concorrenciais e de competitividade intercapitalista na planificação e na gestão dos territórios. A competitividade é uma concepção que rapidamente se incorporou às lógicas de planejamento e gestão dos territórios. Logo, passou a fazer parte do mainstream efeitos de encadeamentos, de especializações, de aperfeiçoamentos, de economias de escala, de externalidades positivas, de inovações e outros como elementos prioritários para a dinamização competitiva e econômica dos territórios. Nossa proposta é demonstrar que a disputa entre os territórios conta com a atuação do Estado, em suas diversas escalas, por meio de políticas públicas, especialmente para atender às demandas corporativas. Uma lógica que essencialmente prioriza uma maior circulação do capital e, por isso, precisa contar com os sistemas de transportes, armazenamento e logística. $\mathrm{Na}$ mesma direção, a logística realizada pelas empresas otimiza os sistemas de engenharia, a fim de minimizar novas construções e custos de produção. Paulatinamente, a busca pela fluidez torna-se a essência da competitividade territorial. No Brasil, os planejadores e gestores públicos incorporaram, para uma maior fluidez e competitividade, o reordenamento dos espaços embasados nos ideais "neoterritorialistas" e neolocalistas.

Palavras-chave: Fluidez; Competitividade; Território; Logística; Sistemas de Transportes.

\footnotetext{
1 Artigo produzido com fragmentos do Relatório de Pesquisa de Pós-Doutorado realizado no Departamento de Geografia, Programa de Pós-Graduação em Geografia no Instituto de Geociências da Universidade Estadual de Campinas (Unicamp), com Bolsa de Pós-Doutorado Sênior (PDS) do CNPq.
}

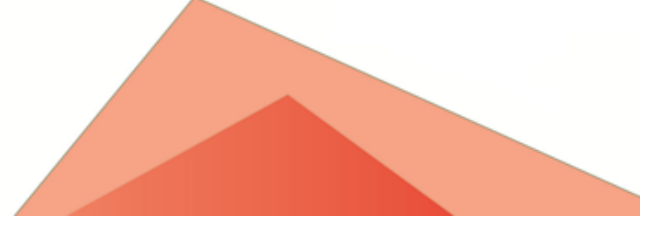




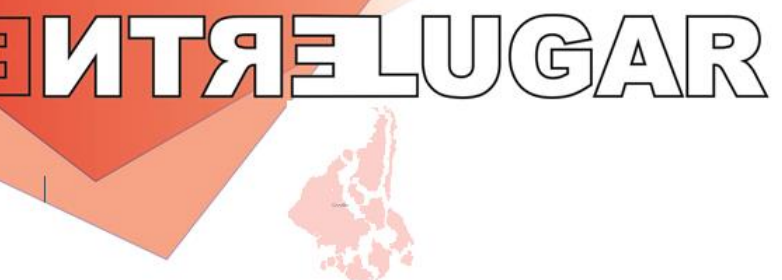

\section{ABSTRACT}

Territorial competitiveness is the use of competitive and competitive intercapitalist principles in the planning and management of territories. Competitiveness is a concept that quickly became part of the planning and management logic of territories. Soon, it started to integrate the main effects of chains, specializations, improvements, economies of scale, positive externalities, innovations and others as priority elements for the competitive and economic dynamization of the territories. Our proposal is to demonstrate that the dispute between the territories depends on the performance of the State, at various scales, through public policies, mainly to meet corporate demands. A logic that essentially prioritizes greater capital circulation and, therefore, needs to have transportation, storage and logistics systems. In the same direction, the logistics carried out by the companies optimize the engineering systems in order to minimize new construction and production costs. Gradually, the search for fluidity becomes the essence of territorial competitiveness. In Brazil, planners and public managers incorporated, for greater fluidity and competitiveness, to reorganize spaces based on the "neoterritorialist" and "neolocalist" ideals.

Keywords: Fluidity; Competitiveness; Territory; Logistics; Transportation Systems.

\section{RESUMEN}

La competitividad territorial es el uso de principios competitivos intercapitalistas y competitivos en la planificación y gestión de territorios. La competitividad es un concepto que rápidamente se convirtió en parte de la lógica de planificación y gestión de los territorios. Pronto se convirtió en parte de los principales efectos de las cadenas, especializaciones, mejoras, economías de escala, externalidades positivas, innovaciones y otros como elementos prioritarios para la revitalización económica y competitiva de los territorios. Nuestra propuesta es demostrar que la disputa entre los territorios se basa en el desempeño del Estado, en sus diversas escalas, a través de políticas públicas, principalmente para satisfacer las demandas corporativas. Una lógica que prioriza esencialmente una mayor circulación de capital y, por lo tanto, debe basarse en los sistemas de transporte, almacenamiento y logística. En la misma dirección, la logística realizada por las empresas optimiza los sistemas de ingeniería para minimizar los nuevos costos de construcción y producción. Gradualmente, la búsqueda de la fluidez se convierte en la esencia de la competitividad territorial. En Brasil, los planificadores y gerentes públicos se unieron, para una mayor fluidez y competitividad, a la reorganización de espacios basados en los ideales "neoterritorialistas" y "neolocalistas".

Palabras clave: Fluidez; Competitividad; Territorio; Logística; Sistemas de Transporte.

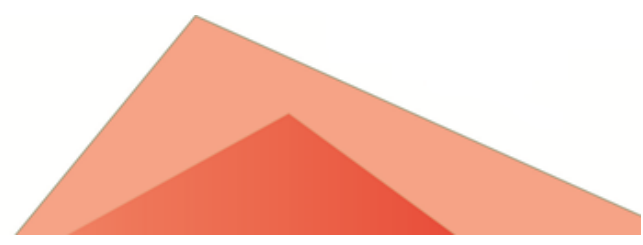




\section{INTRODUÇÃO}

O que se chama de competitividade territorial nada mais é do que o uso de princípios concorrenciais e de competitividade intercapitalista (criada e utilizada no ambiente corporativo) na planificação e gestão dos territórios. São, portanto, concepções que se impregnam no território a ponto de se tornarem partes intrínsecas da sua estrutura de planejamento, investimentos e gestão. Os atributos da competitividade são absorvidos pelos agentes especuladores e produtores do território. É por intermédio destes agentes e dos investidores externos que estes atributos se institucionalizam no Estado. A sociedade, com isso, assume o papel de gerenciar e ampliar a competitividade, por meio de políticas públicas, do movimento do capital e da exploração do trabalho. Consequentemente, há um efeito de encadeamento, especialização, aperfeiçoamento (produtos e processos), economia de escala, inovação e outros elementos que dinamizam economicamente o território, "tornando-o mais competitivo".

Não é um ou outro espaço que fica mais competitivo, mas sim determinados agentes que estão presentes nele e que possuem maior capacidade de organizá-lo. Esses agentes, por intermédio do território, atuam como forças capazes de atrair investimentos e de ampliar as suas capacidades de competitividade e de rentabilidade. Entre eles está o Estado que nada mais é do que um campo onde as classes se confrontam. Por isso, não dá para entender a "competitividade entre os territórios", um espaço impregnado e produzido por diversos agentes sociais, sem entender o papel da União (governo central), do Estado federativo (governo estadual) e especialmente dos municípios (governo local). É no âmbito dos municípios que ocorre a legitimação das leis, das normas e das discussões sobre a produção e o ordenamento de um espaço mais coeso aos interesses seletivos das grandes corporações.

Há situações que mostram que esse efeito de encadeamento tomou proporções tão grandes que levaram nações à prosperidade: as nações mais ricas são aquelas que passaram por um período de inovação e a maioria delas começou por

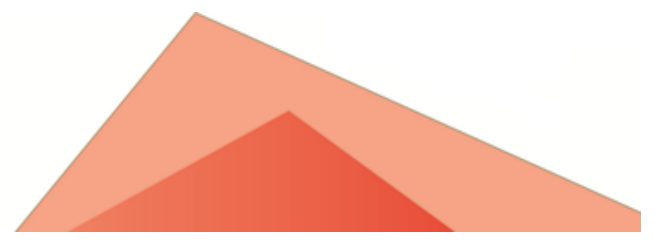


longos períodos imitando outras que tiveram um desempenho superior. As inovações, o aperfeiçoamento via imitação, a expansão do mercado, o aumento do consumo interno, mas também a estabilidade política, como no Império Mugal, foram elementos que aceleraram o desenvolvimento de diversas economias. Fazer parte de uma destacada cadeia produtiva e de circulação pode colocar um determinado território em vantagem em relação a outros.

O caso de Roterdã, na Holanda, é exemplar, pois é um espaço que se especializou na circulação de mercadorias entre a Holanda e suas colônias, possessões etc. Mas, com o tempo, passou a ser a principal porta de entrada e de saída da Europa. Posteriormente, o território ampliou seu know-how nas atividades portuárias e marítimas por intermédio do desenvolvimento da tecnologia da informação, da sede de empresas de seguro e resseguro, de companhias e serviços marítimos e portuários, no abrigo de sede de corporações europeias (especialmente porque está se destacando como uma cidade inteligente), sede de startups e outros. A modernização portuária das últimas décadas é um fator de grande economia de espaço e, com isso, as grandes áreas ociosas do porto de Roterdã passaram a movimentar o setor da construção civil para moradias e escritórios empresariais. Mas não vamos nos enganar: o sucesso do passado, das pequenas escalas territoriais, tinha relação intrínseca com o sistema econômico da época, que permitia que territórios com relativa autonomia político-administrativaeconômica (comportavam-se como nações) tivessem sucesso. Hoje, depois de ampla implementação dos ideais e das políticas de desenvolvimento territorial e local, os países nórdicos e os Países Baixos observam o esgotamento do modelo. Eles veem-se, a duras penas, as suas principais empresas, símbolos nacionais, sendo adquiridas por empresas estrangeiras, inclusive por chinesas.

A competividade territorial, na sua forma mais geral, não é algo novo, por mais que muitos dos elementos que estão presentes hoje não fossem comuns em tempos pretéritos. Foi observada, por exemplo, tanto na China quanto na Índia, durante o desenvolvimento de seus apogeus comerciais, uma especialização produtiva (seda, têxteis de algodão, cerâmica, construção naval) e de circulação (devido à competição entre cidades portuárias e de entrepostos terrestres, como na rota da seda e no mar da

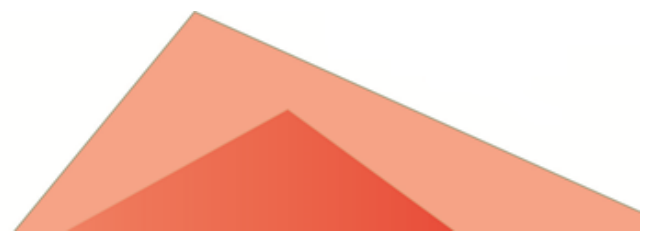


China e oceano Índico) que gerou no território uma forte especialização e divisão do trabalho, inovações técnicas e organizacionais, economias de escala e, por conseguinte, concentração e centralização do capital (passando fases concorrenciais e oligopolistas). Mas nada disso ocorreu por acaso. A presença do Estado foi marcante, como investimentos diversos (como o financiamento para desenvolvimento de inovações), a redução de impostos e outros, ou seja, criando um ambiente favorável à competitividade. A força do Estado, seu poder de coerção econômica e extraeconômica, são também elementos desse processo e, portanto, sem isso, tudo seria mais difícil.

Entretanto, muitos Estados não conseguem gerar, controlar, direcionar e aproveitar o processo de desenvolvimento em seu território. Isso permite desigualdades espaciais, pois muitos - nas suas mais diversas instâncias e escalas - não controlam os fatores essenciais da competitividade, não conseguem estabelecer um planejamento e gestão eficientes, inclusive no que diz respeito à fluidez territorial, um dos elementos cruciais da competitividade. Quando o grande capital consegue impor sua seletividade devido a falhas ou poucos filtros do Estado na direção da soberania - o que vemos são territórios que participam das cadeias globais de produção e distribuição numa posição subalterna na divisão internacional do trabalho, como ocorre na "Região das Maquilas" (México) e em importantes partes do território brasileiro. As "revoluções e evoluções logísticas" - uma série de explosões e transformações continuadas no setor de transportes e logística e seus impactos territoriais - são elementos para compreendermos o papel do aumento da circulação no desenvolvimento das forças produtivas e das relações de produção, ou seja, como essas revoluções e evoluções atuam ao permitirem o aumento da competitividade territorial e comporem estruturas espaciotemporais (SANTOS, 2008) complexas e diversas.

Por ora, não discutiremos profundamente o tema revoluções logísticas. O ponto principal do artigo é sobre a mais hodierna reestruturação econômica, chamada por muitos de "globalização", e sua capacidade de indução de novos territórios estratégicos, compostos de regiões e cidades, id est, nas escalas subnacionais, com práticas e discursos de desenvolvimento territorial e local autônomos (embasados nos neolocalismos e "neoterritorialismos"). Independentemente das escalas, os países e as

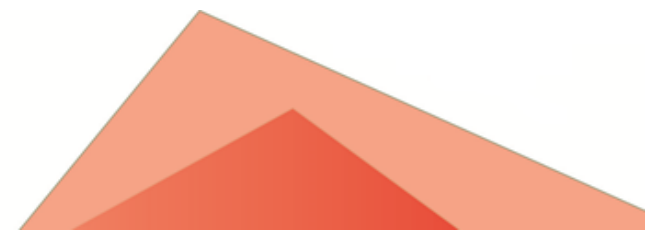


empresas são dependentes da competitividade. Porém, a lógica da competitividade corporativa vai paulatinamente afetando as escalas subnacionais. Nossa intenção, ao discutir o desenvolvimento territorial autônomo, é também relatar as estratégias competitivas utilizadas nos sistemas de transportes e logística.

\section{BREVE EVOLUÇÃO: ALGUMAS CARACTERÍSTICAS DA COMPETITIVIDADE ENTRE OS TERRITÓRIOS}

O final do século XX foi marcado por reformas promovidas nos Estados, especialmente pela menor intervenção destes na economia. Também pelo desenvolvimento das novas Tecnologias da Informação e Comunicação (TIC), pelas modificações ocorridas na organização da produção (modelos fordista-keynesiano), pela internacionalização das economias e por um mercado "mais" competitivo e globalizado. Tudo isso, por conseguinte, conjugado com a menor participação dos Estados nacionais, a par do aumento da população urbana e das suas novas funcionalizações, trouxe não só um maior protagonismo aos territórios como lhes atribui certa autonomia e responsabilidades acrescidas, além de induzir as condições necessárias para a ascensão de novos territórios estratégicos (regiões e cidades). Isso quer dizer que a competitividade entre os territórios ganhou um novo impulso com o desenvolvimento da mundialização do capital (globalização econômica). Uma nova característica foi fundada, isto é, um novo tipo de competitividade entre os territórios embasa-se na autonomia política, ambiental, econômica e social. A gestão disso tudo passou a ser o foco primordial. Entrementes, temos que ter claro que os discursos são diferentes das ações, pois no tocante geral, essa autonomia é muito mais complexa do que as abstrações que foram realizadas.

Por outro lado, temos que ter claro que os territórios que obtiveram mais sucesso foram os denominados de Zonas Econômicas Especiais (ZEEs), com ocorrência na China, só que com um grande diferencial: o processo foi destacadamente comandado pelo Estado chinês e pelo Partido Comunista da China (PCCh). Nos Estados Unidos, por exemplo, essa autonomia é uma caricatura da realidade, especialmente porque a 
União e as escalas subnacionais subsequentes (com importante autonomia) aportam positivamente os espaços menores, com subsídios, financiamentos, pesquisa e desenvolvimento, geração de renda elevada e alto poder de consumo da população, além de forte atuação geopolítica a favor da sua economia, como a guerra comercial com a China. Contudo, isso não implica negar que não haja algum nível de independência e um padrão neoliberal de atração e competitividade dos territórios. Tanto que o Vale do Silício é um espaço combinado de novas ideias e de especulação financeira e imobiliária, resultando em uma taxa de falência de $90 \%$ das startups cuja culpa, em muitos casos, é atribuída à falta de apoio do governo e à alta dependência dos fatores de mercado.

O que é mais comum é essa ideologia de mercado - que domina o território e impute nele a ideia de autonomia e de autogestão etc. - adentrar com mais frequência nos países da periferia do sistema capitalista, como o Brasil. Mas não vamos nos enganar, pois o Estado, em suas diversas escalas, mesmo na periferia é atuante, especialmente no provimento de infraestruturas, normas e tributos. Entretanto, o que predomina são os fatores de descentralização. Logo, o território compete e consegue, até certos níveis, independência. Eles possuem um padrão de competitividade, por mais que se reproduzam amplamente amostras de desenvolvimento territoriais e locais, e as noções que definem esse padrão são diversas. ${ }^{2} \mathrm{O}$ grau de autonomia, de escala de decisão política, econômica, social e ambiental passa, consequentemente, por diferentes filtros das mais diversas escalas das formações socioespaciais existentes.

Países e empresas estão intrinsecamente dependentes da competitividade e, em maior ou menor grau, uns dos outros. Isso quer dizer também que, cada vez mais, as empresas competem por intermédio dos fatores estatais que estão contidos nos territórios. Isso era mais comum entre os Estados-nacionais e menos comum entre as escalas subnacionais. Atualmente é o contrário. Contudo, a eficiência não mudou tanto

\footnotetext{
${ }^{2}$ Para Lopes (2001), a problemática da competitividade, subjacente a toda história da teoria econômica desde que Adam Smith (1776) se interrogou sobre as causas da riqueza das nações, não só emergiu explicitamente nos anos 1990, como adquiriu lugar cativo nas agendas empresariais, políticas e acadêmicas (ALVES, 2009, p. 04).
}

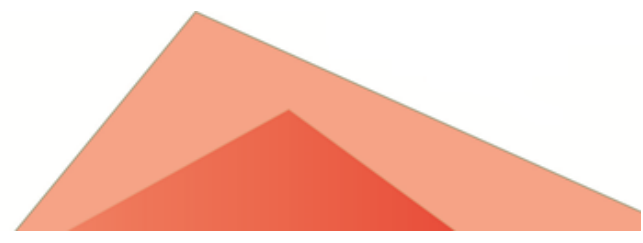


assim, pois é a escala da União, se possuidora de capacidade soberana, a que mais consegue resultados na disputa com outros territórios.

Há uma multiplicidade de determinações que definem a forma de competitividade territorial entre os espaços. Isso dificulta a formalização de um conceito claro e objetivo. Mas, o conceito não deve ter só como parâmetro a mediação da performance das economias regionais. Podemos dizer que há mais elementos que o que apresentam os tradicionais indicadores econômicos e sociais, pois eles são basicamente o resultado das diversas ações e consequências (internacionais, nacionais e locais) do que propriamente de um conjunto organizado de ações dos entes regionais e locais na indução do desenvolvimento. Claro que não devemos esquecer o que apregoava John M. Keynes sobre a socialização dos investimentos. Só que a socialização dos investimentos só ocorre por meio de uma política de desenvolvimento ativadora de demandas que sejam "realmente" efetivas. Essa afirmação tanto é fato que, atualmente, depois de constatação do fracasso das políticas neoliberais, surge uma nova proposta, que ganha força na Europa, e é baseada nas políticas do New Deal, retiradas das propostas de Keynes. Estamos falando do Green New Deal. ${ }^{3}$

Ainda assim, é de corrente aceitação que a competitividade territorial é a capacidade de uma dada comunidade territorial para assegurar as condições econômicas do desenvolvimento "sustentado". No atual conceito estão presentes ideias como: capacidade de inovar, concorrência e estratégia, acesso (TIC e mercados) e conhecimento tácito e codificado. "Um pouco como a globalização, a repetição do termo 'competitividade' produz muito calor e pouca luz" (ALVES, 2009, p. 05). Isso mostra que a competitividade se tornou um termo genérico, aplicado extensivamente para uma variedade de negócios e circunstâncias econômicas. Desse modo, é necessário muito cuidado ao usar o termo e, com isso, evitar generalizações excessivas, como ocorre com outras formulações, como globalização, logística, reestruturação, revolução etc. Os exemplos mais claros estão contidos nas ideologias neoliberais que, ao refutarem maior intervenção do Estado na economia, reduzem as políticas de

\footnotetext{
${ }^{3}$ Combina abordagens econômicas de John M. Keynes, utilizadas pelo Presidente dos Estados Unidos Franklin D. Roosevelt, com ideias de sustentabilidade ambiental, energias renováveis e uso eficiente de recursos.
}

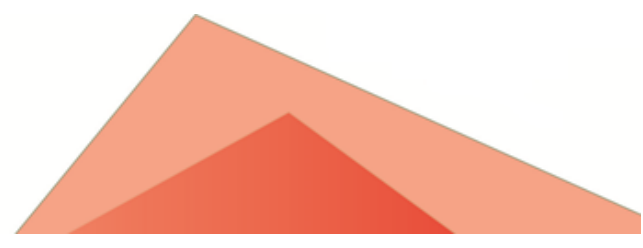


desenvolvimento territorial à competitividade entre as corporações. Entrementes, as teorias keynesianas preconizam uma maior intervenção do Estado na formulação das políticas de desenvolvimento territorial. Só que elas estão comprimidas em algo que é muito maior que a autonomia preconizada pelos neoliberais, ou seja, em uma macroeconomia mais planificada.

Mas o território não é uma escala social isolada e exclusivamente dependente de seus atributos internos. Até porque o espaço não é um receptáculo das ações e ele próprio, conforme Santos (2008), é social. O território está inserido num ambiente que é composto por meios sociais complexos - como a economia - e em constantes interações. Isso outorga diferentes escalas de poder e interações espaciais. Essas multiplicidades de determinações - ademais emanadas de outros territórios -, que cercam os territórios e interagem com eles, permitem inclusive que eles tenham capacidade e parâmetros de autogestão que possam induzir o crescimento econômico. Portanto, nada está isolado a não ser que esteja verdadeiramente sozinho. Isso mostra que os territórios não estão realmente apartados e que há entre eles diferentes níveis de integrações/interações espaciais (como um espiral de escalas em movimento e se alimentando mutuamente).

O que se busca com a competitividade entre os territórios é a expansão da sua capacidade de polarizar (atrair), centralizar empresas (também através de Arranjos Produtivos Locais - APLs), capitais e informações. Muitos conseguem gestar empresas (indústria nascente) enquanto outros possuem uma maior capacidade de atração de investimentos. São, portanto, inovações diferenciadas. Uns centram-se mais em alta tecnologia, desenvolvimento de produtos $(\mathrm{P} \& \mathrm{D})$, produção de alto valor, distribuição (adicionamento de valor) e outros escolhem investir na montagem final (montadoras). Mas, também há os que optam pela comercialização de produtos e serviços mais imediatos, como cidades-polo comerciais e turísticas.

É a forma como se usa o território que está impregnada de elementos da competitividade corporativa. Há uma intensidade tão grande que o território deixa de ser só o fornecedor e o alicerce necessário à competitividade e ele próprio passa a agir como um competidor, no sentido que as instituições e sua sociedade assumem esse

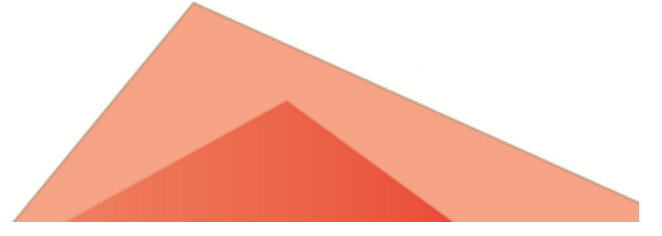


caráter. Muitas vezes isso alcança níveis insustentáveis que prejudicam o próprio território, especialmente quando as empresas concentram e centralizam grande quantidade de recursos públicos (através de isenções, subsídios, refinanciamentos e outros) que suprimem os investimentos sociais (em infraestruturas sociais e serviços coletivos), como saúde, educação, assistência social, saneamento, habitação, mobilidade urbana e outros e, especialmente, quando não há socialização dos investimentos aplicados. As aplicações desse método às políticas regionais resultam em distorções no desenvolvimento econômico.

Uma coisa é certa, a transnacionalização de muitas atividades econômicas realçou as posições das cidades-regiões. A globalização pode parecer incerta e incompleta, mas as cidades/regiões podem aproveitar-se dos processos internacionais a fim de manter e aumentar as vantagens e especializações comparativas das suas atividades. São regiões que, especialmente na periferia do sistema capitalista, possuem uma cidade-polo concentradora e centralizadora (capitais, informações, mão de obra qualificada, investimentos e outros) em detrimento da sua hinterlândia e de outras regiões. A concentração de renda gera tantas desigualdades sociais e espaciais internas quanto externas (entre as regiões, quer dizer, desigualdades regionais).

Vivemos numa época em que a realidade objetiva importa menos que os indicadores econômicos que, em muitas situações, são instrumentos (devido às metodologias tendenciosas) pouco eficazes de medidas de desenvolvimento. Isso coloca um fato inevitável: as regiões e cidades, independentemente de suas estruturas, processos, funções e formas são comparadas umas com as outras, levando em conta seu desempenho econômico e seus outros atrativos como fatores importantes da competitividade. Os países fortes competem entre si e usam seus territórios seletivizados para isso (o que reforma muitas vezes a competitividade territorial) e os fracos, ao permitirem e autorizarem maior autonomia às suas escalas subnacionais, perdem soberania. A descentralização política e econômica - colocando em evidência a autonomia para endividamento, relações e comércio internacionais, ou seja, diminuindo a soberania do Estado-nação - é o principal caminho. Isso tudo são alguns dos atributos que tornam esse jogo competitivo injusto e extremamente agressivo para certas nações e

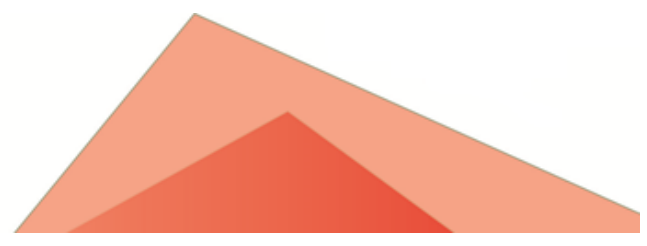


seus territórios. Não há governança, cooperação e inovações capazes de serem desenvolvidas nas escalas subnacionais que substituam a importância do Estado nacional frente à voracidade de um "mercado" que utiliza o poder das grandes nações imperialistas. Não há, a não ser num imaginário idealista, ilhas de prosperidade envoltas à miséria. Pelo menos sem serem afetadas indiretamente pela pobreza à sua volta.

Ao entrarem no jogo do desenvolvimento territorial e local os países periféricos têm pouco a usufruir. Pelo menos, em grande medida, falta-lhes algo essencial, ou seja, uma alta capacidade de manipulação da sua macroeconomia. Estamos falando de financiamento e investimento do desenvolvimento e poupança nacional (sistema de intermediação financeira), do câmbio, do controle das barreiras alfandegárias, das reservas cambiais e também das relações internacionais, da defesa nacional etc. $\mathrm{O}$ que as economias subalternas fazem é oferecer, colocar à disposição um roll de elementos que possam tornar as corporações mais competitivas. Dizem que com isso os territórios tornam-se competitivos. Está aí uma das principais vertentes do desenvolvimento territorial e local - pelo menos a que é mais comum no mundo. Os atributos típicos desse novo estágio do capitalismo oferecidos pelas nações da periferia do sistema geralmente são: 1) legislação favorável para instalação e circulação de mercadorias, capitais e informações, sobretudo a tributária - muitas vezes essas facilidades são unilaterais (entrada de insumos para comporem produtos comercializados no mercado nacional e saída de commodities); 2) tributos, isenções, impostos menores, sistema tributário facilitado e desburocratizado; 3) incentivos fiscais para aquisições de terrenos, de plantas empresariais, contratação de mão de obra (reformas trabalhistas e previdenciárias) e outros; 4) infraestruturas de transportes e armazenamento, além de TIC coligadas à movimentação de mercadorias que, por conseguinte, facilitam um amplo processo logístico (estratégia, planejamento e gestão dos transportes e do armazenamento); 5) aplicação da logística moderna (seja ela de Estado através de diversas ações para favorecer a fluidez territorial ou a corporativa, especialmente com o aprovisionamento de conhecimento, id est, mão de obra especializada) como um grande elemento de inovação, uma categoria organizacional, imposta como um tributo essencial do território competitivo; 6) mercado consumidor

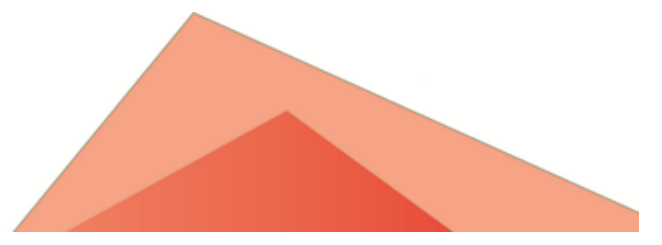


focado em certos tipos de mercadorias das grandes corporações: devemos ter em conta que esses territórios ditos competitivos, na periferia, na verdade são plataformas para acessar os mercados/regiões com padrão de consumo mais elevado e certos tipos de insumo (agrotóxicos, rações, implementos agrícolas diversos etc.).

A disputa entre os territórios resume-se ao oferecimento de amenidades naturais (terra, biodiversidade, minérios e outros) e artificiais como fatores essenciais para localizações das atividades econômicas. Nesse jogo de quem oferece mais existe uma diferença entre as nações e os territórios mais e menos desenvolvidos e soberanos. Para uma empresa acessar o mercado americano, alemão e especialmente o chinês ela geralmente oferece mais do que recebe. A joint venture é talvez a principal peça dessa negociação. Por outro lado, nas economias periféricas, poucos acordos de joint ventures são negociados e, com isso, é comum que elas ofertem mais do que recebem. O Brasil começou a romper essa lógica de desenvolvimento territorial periférico quando implementou, nos governos Lula da Silva e Dilma Rousseff, conteúdo nacional mais elevado para a indústria naval e outros setores; quando empresas estatais aumentaram as compras no mercado nacional (como a Petrobrás); quando se estabeleceu joint ventures para produção de caças e submarinos nucleares e quando se tentou fazer o mesmo com a locação do trem de alta velocidade entre os estados de São Paulo e do Rio de Janeiro.

Quer dizer que a competitividade territorial, e muito do que se chama de desenvolvimento territorial, é um complexo conjunto de fatores de localização de atividades econômicas (de produção, circulação, troca e consumo), com a finalidade de atrair investimentos diretos e de rápida circulação (como os indiretos, por meio de territórios amplamente especulativos, como os paraísos fiscais, os com taxas de juros elevadas etc.). Assim, os territórios, muitas vezes entendidos como "sujeitos" autárquicos, fazem de tudo para alcançar um "ótimo" para atração de investimentos. Um "ótimo" que pode ser composto por outras determinações - por mais que na prática elas sejam mais distantes das realidades periféricas do que as do centro do sistema capitalista -, como: 1) a criatividade do empregado, maior nível de conhecimento e a criatividade embutidos na cultura e na formação socioeconômica de uma nação e/ou região - melhor formação de recursos humanos; 2) o fator capital, produção e informação, como

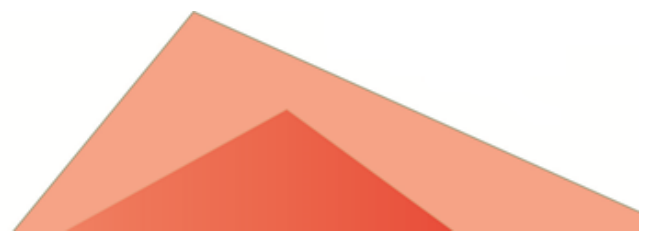


melhores níveis das TICs que permitem reduzir distâncias por meio de um rápido acesso à informação (vide o boom das fibras ópticas); 3) o conhecimento tácito (produzido na própria região etc.) do qual o desempenho das empresas depende cada vez mais; 4) a interação local e troca de conhecimento (sourcing) para inovação de processos, inclusive para além da região, pois muitas empresas locais possuem capacidade de absorver conhecimentos fora da região (o papel das universidades públicas e dos centros de pesquisa, como a Embrapa, é fundamental no Brasil, especialmente porque poucas empresas possuem capacidade de P\&D); 5) a inovações sociais e institucionais, como a criação de um clima social que combata a inércia e que faça as pessoas acreditarem e a criação de redes locais de cooperação; 6) a presença de instituições públicas (potencializando os territórios com projetos) locais e regionais.

Por fim, também há uma diferença entre os territórios que buscam criar condições para atração de investimentos e os que estão mais voltados para a geração endógena de desenvolvimento. Esse último é menos comum nas economias periféricas que, por isso, utilizam muito menos os seis tópicos supracitados do que outros espaços mais proeminentes. É muito por influência europeia que essa discussão, um pouco mais romantizada, difunde-se pelo mundo. Ela disponibiliza o território como fator determinante para o desenvolvimento regional (ALVES, 2009). A competitividade dos territórios ganhou um novo impulso e tornou-se uma realidade indissociável do desenvolvimento da globalização (ALVES, 2009). A economia global contemporânea reserva um importante protagonismo aos territórios. Isso também coloca em evidência que na atualidade a competitividade diferencia-se muito de espaço para espaço. Uns baseiam-se mais nos tradicionais custos dos fatores de produção (mão de obra e matérias-primas) e outros se confrontam com uma realidade alimentada pelo conhecimento e pela inovação. Não há nenhuma novidade até aqui e também não há nada que "escape aos olhos" de um Estado nacional mais ou menos soberano. Assim, criticamos um falso discurso sobre a competitividade territorial.

Fala-se em competição territorial para colocar em destaque como as empresas deixam de competir singularmente, e sim como sistema, utilizando-se de um conjunto de capacidades produtivas, de capital físico e humano, de infraestruturas e de

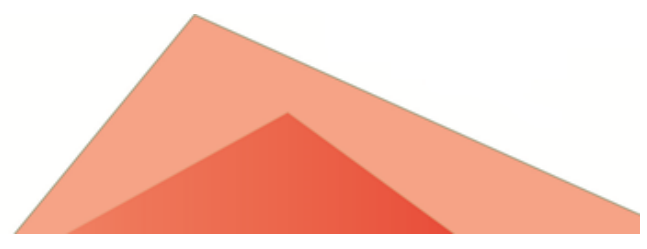


redes, de capacidades inovacionais, de eficiência total do sistema territorial local. As empresas utilizam, extraem e potencializam essas características para seus interesses. É um processo de sucção que, em muitas situações, desnuda o território. E, por trás disso tudo estão ideologias, como de empreendedorismo, inovação social, cooperação e governança, comunicação etc. Logo, os teóricos, ideólogos do desenvolvimento e da competitividade territorial e local vão criar e utilizar planejamentos estratégicos que transformem os tradicionais jogos de uma "soma zero" para um de "soma positiva". A questão posta é: isso dá certo e em quais condições? Uma coisa é certa: a capacidade de competição de um sistema local, portanto, mede-se tanto em termos de recursos, investimentos e empresas que conseguem atrair de outras áreas quanto em inovações nos produtos, nos processos, nos mercados e nos modelos organizativos que é capaz de gerar (CICIOTTI, s.d.). Mas quem consegue fazer isso, ou seja, gerar endogenamente? Quem consegue e em que condições gestar bons desempenhos e atrair empresas de fora (nascimento e atração) e gerar novo "empreendedorismo"? É na direção de realizar críticas ao desenvolvimento neoterritorialistas e neolocalistas que encaminhamos a presente discussão.

\section{A RECENTE EVOLUÇÃO DAS POLÍTICAS DE DESENVOLVIMENTO TERRITORIAL NO BRASIL}

O Brasil, a partir da década de 1980, adentrou numa crise econômica e também institucional (crise cíclica internacional e interna), com uma política que comprometeu a recuperação econômica interna, advinda das consecutivas substituições de importações. Independentemente da nova Constituição Federal (em 1988), que também alterou a capacidade das escalas subnacionais na proporção da arrecadação, o Brasil passou por governos que fracassaram na tentativa de recuperar a economia, até emergirem no século XXI, no governo Lula da Silva, políticas voltadas à retomada do desenvolvimento econômico e social.

Um dos fatos que marcaram a trajetória de fracassos foi a abrupta abertura da economia na década de 1990, com o governo Fernando Collor de Mello, seguindo seu aprofundamento com o governo Fernando Henrique Cardoso (FHC). A inserção do

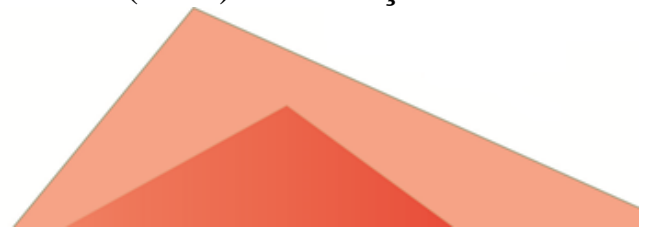


Brasil no mercado internacional, com os governos Collor e Cardoso, foi submissa ao ponto de amenizar os efeitos internos da recuperação da economia internacional, mantendo o Brasil numa crise que durou até 2003. Especialmente pelo efeito de uma série de concessões e desnacionalizações de empresas públicas estratégicas. Em vista disso, foram mais de duas décadas de crise que afetaram tanto o comércio externo do Brasil (com déficits crescentes na balança comercial e de pagamentos) quanto o mercado interno.

\section{Alguns elementos dos "neolocalismos" e "neoterritorialismos" competitivos no}

\section{Brasil: descentralização e renúncias fiscais na competitividade entre os territórios}

Na década de 1960, Ignácio Rangel tratava da distopia da alocação dos recursos fiscais pelo território brasileiro, das desigualdades territoriais e da necessidade de encorpar e unificar primeiramente o mercado nacional antes de praticar "aventuranças" com fitos neoliberais no mercado mundial. Em pleno século XXI a lição de Ignácio Rangel ainda não foi apreendida. "Peripécia" que, sob os auspícios do neoliberalismo, enraíza-se, cada vez mais, sob a ótica de uma descentralização fiscal e administrativa que enfraquece a planificação nacional e regional e que, à vista disso, se repercute nas novas políticas de desenvolvimento territorial e local, id est, os neolocalismos e os neoterritorialismos.

Formou-se, ao longo do tempo, no debate público, uma corrente de pensamento de valorização da descentralização administrativa e tributária. Na década de 1980 a descentralização passou a ordenar as reformas do setor público. Acabou gerando um consenso que passou a ser advogado por conservadores e socialdemocratas. Os adeptos do fortalecimento dos níveis subnacionais de governo enalteceram a sua capacidade de robustecer a democracia e produzir uma maior eficiência alocativa no sistema de governo (MELO, 1996). Advieram a identificar a competição entre as diversas escalas das unidades federativas como geradoras de inovações no sistema público. Por outro lado, muitos afirmaram que são os estados federativos e municípios o lócus do clientelismo, da influência, da irresponsabilidade fiscal, do endividamento e que eles podem comprometer os esforços de estabilização do governo central. Sua

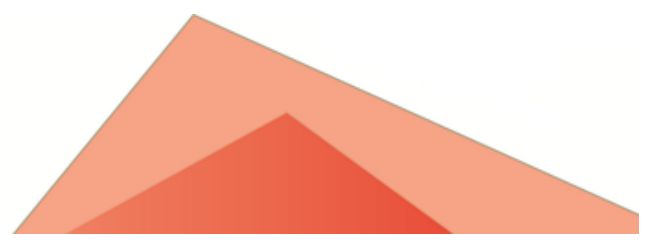


autonomia pode suscitar problemas de governabilidade e inclusive interferir na escala nacional. A guerra fiscal entre os estados e municípios representaria a perda de rumo e a ausência de coordenação quanto à estratégia nacional de desenvolvimento.

É nesse ínterim que Vainer (2007) fala de um pacto territorial democraticamente construído. Todavia, uma reforma fiscal ampla necessita de um vasto apoio político que, por conseguinte, governos de coalizão no Brasil não conseguem realizar. Recentemente, a discussão sobre equalização do Imposto sobre Circulação de Mercadorias e Serviços (ICMS), pelos Decretos n ${ }^{\text {os }} 442 / 2015$ e 953/2015, tornou-se um debate exaustivo e pouco significativo. Na mesma direção foi a discussão sobre a distribuição dos royalties de petróleo e gás entre os estados federativos e municípios e também para a educação e para a saúde. O que mostra que o conflito entre entes federativos subnacionais e a União está longe de acabar.

A descentralização foi incluída como uma das bandeiras da democracia, especialmente para os países egressos de experiências autoritárias, como para a América Latina e notadamente para o Brasil. ${ }^{4}$ A descentralização passou a fazer parte da essência da redemocratização. Destarte, no caso da China, o poder central é mais atuante no planejamento e nos investimentos, ou seja, no projetamento e, portanto, na organização espacial, com inclusão de significativas mudanças socioespaciais, como a erradicação da pobreza e crescente inclusão em um modelo, na versão chinesa, de "estado de bemestar" social. Isso coloca em evidência o papel do governo central no ordenamento do território e a forma como é a hierarquia entre entes governamentais e como a União se articula às escalas subnacionais de poder. Também é comum o governo central e as escalas subnacionais passarem por crises fiscais, pois não conseguem conter e/ou superar as determinações neoliberais das escalas supranacionais, tanto a da União Europeia quanto da global (lembrando que os países da União Europeia são, em grande medida, os Estados múltiplos, tratados por Ellen Wood). Logo, há limitações na descentralização. Presentemente, há um processo mais acelerado de investimentos e desenvolvimento nacional, regional e local nas nações que conseguiram somar

\footnotetext{
${ }^{4}$ A genealogia da descentralização enquanto princípio político remonta o pensamento liberal. Desde Tocqueville, as virtudes do local self-government, entendido sobretudo em relação à intervenção do Estado Central, tem sido inteiramente enaltecida por liberais. No campo econômico é celebrada por Hayek a Buchanan (MELO, 1996).
}

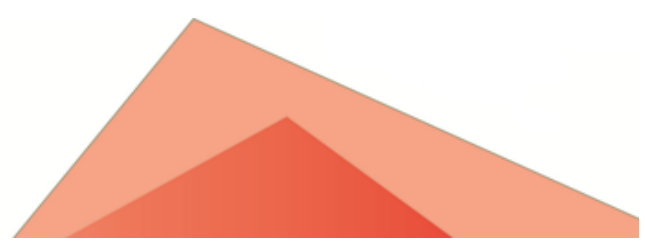


centralização, projetamento e crescimento econômico, como na China, na Índia, na Rússia, na Coréia do Sul, entre outras.

O ideal da descentralização torna-se, gradualmente, um princípio meritório entre os quadros da esquerda, sobretudo da chamada esquerda pós-industrial, além de ser consistente com a visão de fragmentação social que domina o chamado pósmodernismo na teoria política (MELO, 1996). Uma ideia que ganha força por meio da inaptidão do Estado de suscitar crescimento econômico, planejamento, financiamento e investimentos. Os planos nacionais e regionais de desenvolvimento, como III PND (1980-5), perderam capacidade concreta de transformar os territórios. A partir daí começa o desmonte do Estado, sua capacidade de planejar, financiar, investir e organizar o setor público, dando lugar aos ditames da descentralização. Fato que levou juntamente com a pressão por austeridade fiscal, com a crise econômica, com o aumento das responsabilidades dos Estados e municípios e com a guerra fiscal - a um “salve-se quem puder". O Estado nacional, paulatinamente, perdeu sua capacidade de mediar e liderar práticas de cooperação federativa. A crise federativa, deste modo, está instalada.

Nada muito diferente do que vinha ocorrendo na Europa, pois países com governos "socialistas", como França, Itália e Espanha, realizaram significativas reformas descentralizadoras. Para os sociais-democratas a ideia estava voltada para um entrincheiramento, resistência, otimização de recursos a partir das escalas regionais e locais. Porém, para os neoliberais a descentralização foi uma peça central do repertório político conservador que tem no governo central uma das "camadas" mais fortes de resistência à sua penetração. Instituições multilaterais, como o Fundo Monetário Internacional (FMI), Banco Mundial, Banco Interamericano de Desenvolvimento (BID), Organização Mundial do Comércio (OMC) e outras, foram veículos de difusão da descentralização, tendo a América Latina como principal alvo e laboratório. Assim, torna-se comum o discurso de desmonte do Estado Central e de redução de sua atividade regulatória e produtiva. A década de 1990 marcou o Brasil nessa direção. 
Abonado pela Constituição Federal de 1988, houve nos governos Collor, Itamar Franco e FHC um processo de descentralização e de enfraquecimento do Estado Nacional. ${ }^{5}$

Houve, a partir de um determinado momento, a necessidade de coalizões entre forças políticas conservadoras e liberais que passaram a enfatizar a descentralização como provedora de ganhos de eficiência e redução de gastos no setor público. Coalizões social-democratas e socialistas, por outro lado, privilegiaram os aspectos relativos ao controle social e à democratização da gestão local. No campo socialista desenvolvia-se a vertente de reformismo como a possibilidade mais concreta. Bem, ambos os lados neoliberais/conservadores (parte deles) e socialdemocratas/“socialistas" convergiram numa coalizão em nome de uma redemocratização pacífica e de uma Constituição Federal direcionada a uma maior inclusão social. Com isso, houve uma visão cada vez mais crescente quanto à promoção da autonomia local, inclusive financeira, voltadas para o federalismo fiscal. Está lançada a "onda" da local policy entrepreneurship. As discussões sobre neolocalismos, neoterritorialismos e destacadamente sobre cidades inteligentes (smart city) consomem atualmente o discurso político e o ambiente acadêmico. São vinculações mais voltadas para um marketing territorial e local que remontam a um grande esforço público por parte dos diversos entes da federação (União, estados e municípios) e, por conseguinte, despendendo grandes gastos públicos (sociais) voltados aos setores privados de consultoria, marketing e outros.

Entrementes, há limites e efeitos (muitos negativos) nas estratégias descentralizantes que sugestionam as políticas de desenvolvimento territorial e local, como: 1) burocracias locais de baixa qualificação - existe um hiato entre a capacidade técnica local e central, especialmente em pequenos municípios do interior, em contrapartida, a expansão do ensino público técnico e superior vem ajudando na superação destas limitações; 2) transferência de receitas públicas sem responsabilidade de geração de receitas, o que rompe o vínculo entre o benefício e o custo (o argumento é

\footnotetext{
5 "Durante os conservadores anos 1990, marcados pelo Consenso de Washington, houve dois governos FHC (1995-2002), em que foram realizadas típicas estratégias de rollback (BRENNER et. al., 2012), de ataque ofensivo e desmantelamento de instituições públicas que regulavam o mercado, liberando suas forças para agir mais livremente. Foi um momento de privatizações, internacionalização da economia, destruição de postos de trabalho, de direitos e garantias, com vigorosa repressão aos movimentos sociais" (BRANDÃO, 2019, p. 261).
}

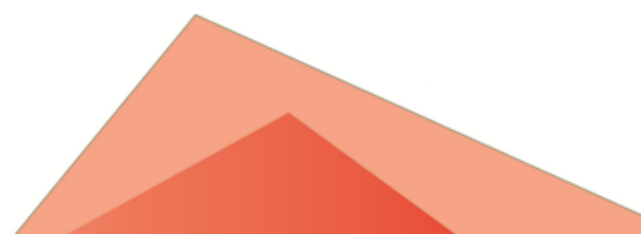


que recursos de transferências são menos monitorados por agentes locais que aqueles resultantes de taxações no nível local); 3) indefinição e ambiguidade quanto à imprecisão de competências entre esferas de governo, devido à generalização de competências concorrentes, gerando paralisia institucional; 4) perda de capacidade regulatória e de formulação de políticas por parte do governo central pelo desmonte das estruturas setoriais centralizadas e relativamente insuladas da competição política (o argumento central é que tais estruturas se constituem em loci de expertise e de memórias técnicas em políticas públicas e dificilmente podem ser encontradas ou mesmo construídas no nível local); 5) descentralização fiscal com transferências de impostos importantes para o nível dos estados e províncias, o que minou a capacidade do governo central de levar a cabo políticas de estabilização e reformas fiscais ${ }^{6}$; 6 ) porosidade do governo local em relação às elites locais e provinciais, acarretando maior corrupção e clientelismo; 7) fragmentação institucional (proliferação de municipalidades ou entes administrativos no âmbito local, uma tendência, segundo vários analistas, observada com grande força no Brasil). Outros pontos são: de quem será a responsabilidade por planejar, financiar, investir e gerir as infraestruturas de ligações entre as escalas subnacionais, como as de transportes? Qual deverá ser o comportamento das agências de desenvolvimento metropolitanas? E assim por diante.

Como tratamos, no que diz respeito ao desenvolvimento local (escala municipal) e territorial (escala regional), o resultado da correlação de forças (a soma) pode ser "zero" ou "negativa", com repercussões predatórias sobre a cidadania social, id est, o "hobbesianismo municipal" (MELO, 1996) e "regional" que se expressam na disputa entre localidades por investimentos (especialmente externos), refletidas nos neolocalismos competitivos (VAINER, 2007). Há, com isso, uma deslegitimação das prioridades sociais em benefícios das fiscais e das isenções tributárias, mas também no provimento de infraestruturas que permitem o aumento da fluidez espacial, com vistas às instâncias corporativas. Os "neolocalismos" e "neoterritorialismos" consagram

\footnotetext{
${ }^{6}$ No Brasil, as dívidas dos estados e municípios com a União, em 2018, chegaram a R $\$ 908$ bilhões e as dívidas consolidadas dos estados e municípios somados chegaram a R \$ 1.052 bilhão (70,2\% empréstimos e financiamentos internos, $11,4 \%$ empréstimos e financiamentos externos, $9,4 \%$ precatórios posteriores a 05/05/2000 vencidos e não pagos e 9,0\% demais dívidas) (BRASIL, 2020). Por mais que tenha acrescido a arrecadação dos estados e municípios também aumentou a sua dívida imobiliária. Houve transferências de responsabilidades para os municípios, mas também houve cessões de recursos da União para eles.
} 
vantagens comparativas locais e regionais por meio das suas reproduções ou potencializações. Os territórios subnacionais são administrados como empresas e, com isso, passam a explorar e construir vantagens competitivas (vantagens comparativas e externalidades positivas). Umas cidades fazem isso na lógica do desenvolvimento sustentável (cidades inteligentes, tecnopolos, entre outros) e outras buscam veementemente por investimentos externos.

A questão é se essas cidades estão sendo realmente levadas ao patamar de "inteligentes", de "sustentáveis" ou tudo isso é mais um ardil achegado aos localismos prósperos? Geralmente essas cidades sustentáveis, inteligentes, embasadas no desenvolvimento local competitivo, estão cercadas de cidades desprovidas de "massa encefálica". As cidades "centrais", as "cidades-polo", muitas vezes, gestam tanto a miséria quanto a prosperidade nas suas "periferias", enquanto se preservam dinamicamente dos efeitos negativos que as cercam. Estamos falando de segregações socioespaciais planejadas - ou seja, jogam para fora do seu "núcleo central" (franja urbana, área periurbana), do município e, muitas vezes, para fora de sua área de influência as atividades econômicas e as "populações tidas indesejáveis". Visualizamos isso em cidades espacialmente periféricas, como as cidades-dormitórios e as que recebem atividades consumidoras de grandes espaços, como aterros sanitários e outras economias poluidoras.

A conclusão a que chegamos é que a maioria dessas políticas localistas são visões pós-modernas falaciosas, expressas num idealismo pós-industrial, pois esses espaços, pelo menos os que são tidos como prósperos, polarizam uma vasta região na qual o incremento sustentável e a "inteligência" da hinterlândia pouco importam. Jogam-se conscientemente "para fora dos seus muros" que, por conseguinte, são territorialmente expandidos, todas as atividades econômicas que prejudicam "a boa imagem": como poluidoras, com muita mão de obra intensiva e pouco capital intensivo, demandantes de grandes superfícies (construídas ou não, como para terrenos para grandes estacionamentos e outros, como os "atacarejos", os shoppings, os atacados, os centros logísticos, os depósitos de automóveis e muitos outros), com salários e relações de trabalho usualmente precários. Mas temos que ter claro que essas cidades não conseguem sobreviver sem polarizar conhecimento e recursos econômicos do seu redor 
imediato ou, até certo sentido, longínquo (dependendo do porte da cidade-polo e a intensidade e formas das diferentes redes que participa). Estamos falando, obviamente de forma mais atualizada, dos "círculos concêntricos de von Thünen" e das "teorias das localidades centrais de Walter Christaller" e, em consequência, da rede urbana. É importante levar em conta também o investimento massivo, em muitos destes espaços, para a atração e produção de atividades de serviços (aumento da terceirização e engrossamento do setor terciário). Muitas sociedades locais percebem as atividades de serviços como uma solução ambientalmente limpa, de boa remuneração, fácil de ser mercantilizada e com retornos econômicos rápidos, com realce para as que capitalizam os serviços superiores.

Assim, são estes os caminhos que muitas cidades - como Campinas/SP, São José dos Campos/SP, São Paulo/SP, Joinville/SC, Florianópolis/SC, Londrina/PR, Curitiba/PR - estão tomando, umas mais e outras menos aceleradas - por mais que elas encadeiem e criem sinergias com suas hinterlândias, fazem isso por meio de fortes divisões territoriais do trabalho. Ainda é importante destacar que a maioria destas localidades são espaços que polarizam muitas atividades públicas (serviços, investimentos, salários e outros). Geralmente são capitais regionais, sedes de governos, sedes de regiões de governo etc. São espaços com inversões e salários públicos altivos, com sedes de empresas, serviços, pesquisa e educação públicas. É também a sede de poder. Tudo isso polariza e ajuda na atração/concentração de atividades privadas. Portanto, independentemente de qualquer política de desenvolvimento local e territorial elas já são líderes, por intermédio do setor público, na produção de riqueza, renda e conhecimento, no poder e gestão do território.

A nova Constituição Federal permitiu aos governos locais aumentar sua participação na receita fiscal. Em alternativa, para recuperar sua receita o governo central tanto cria novos impostos como aumenta os que não estão sujeitos à partilha com estados e municípios, como o Fundo de Participação dos Municípios e dos Estados (FPM e FPE). A Lei de Responsabilidade Fiscal (LRF), sancionada em 04 de maio de 2000, no governo de FHC, objetiva o controle dos gastos da União, estados, Distrito Federal e municípios, condicionando os gastos à capacidade de arrecadação de tributos desses entes políticos. A história contemporânea da política de estabilização brasileira

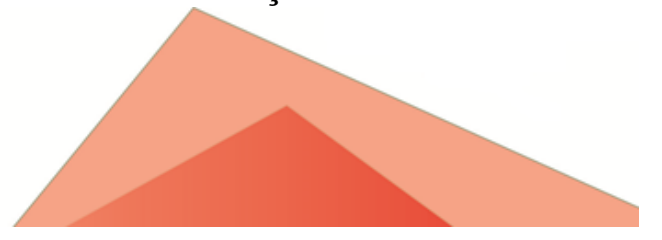


passa a ser permeada por tentativas de garantir maior liberdade alocativa à União e coibir os gastos de estados e municípios (MELO, 1996). Quando Lula da Silva assume o governo, em 2003, a responsabilidade fiscal torna-se uma amarra que inibe a realização dos investimentos públicos prometidos na campanha eleitoral. A alternativa foi livrar-se de algumas delas e aumentar a arrecadação para ter liberdade e recursos para inversões prioritárias. A União, portanto, estava com baixa capacidade de endividamento (devido aos seus elevados níveis) ${ }^{7}$ e de ampliação de impostos. A escolha foi redirecionar os gastos, buscar receitas no superávit comercial e expandir o mercado interno, criando as bases para importantes inversões, notadamente a partir de 2007, com o Programa de Aceleração do Crescimento (PAC).

A Constituição de 1988 permitiu aos estados autonomia para fixar as bases dos impostos de competência estadual, notadamente o ICMS, um imposto sobre valor adicionado. Com isso, os estados passaram a praticar renúncias fiscais massivas para atrair novos investimentos. Algo que os municípios também advieram a realizar, utilizando-se do Imposto sobre Serviços de Qualquer Natureza (ISS) e, até mesmo, do Imposto Predial e Territorial Urbano (IPTU). Também se tornou comum a coparticipação entre estados e municípios na atração de investimentos. Mas há uma variedade de desenhos de incentivos na atração de empresas que vão muito além das renúncias fiscais. As renúncias fiscais levaram à diminuição da carga tributária agregada de um tipo de imposto que representa quase um terço da receita tributária do país. O ICMS representou, em 2016, uma porcentagem de 27,9\% de toda receita, enquanto a contribuição previdenciária foi de 14,6\%, o Programa de Integração Social/Contribuição para o Financiamento da Seguridade Social (PIS/Confins) foi de 14,4\%, o Fundo de Garantia do Tempo de Serviço (FGTS) foi de 7,5\%, o Imposto de Renda Pessoa Jurídica (IRPJ) foi de 7,1\%, o Imposto de Renda Pessoa Física (IRPF) foi de 4,6\% e o ISS foi de 3,9\% (BRASIL, 2018). ${ }^{8}$ As renúncias fiscais fazem falta aos cofres públicos

\footnotetext{
${ }^{7} \mathrm{O}$ endividamento de estados e municípios não tem tanta origem fiscal, mas nas taxas de juros do Plano Real. Ainda há a crise dos bancos públicos associada ao processo de estabilização. Os custos de implementação do Plano Real foram elevados.

${ }^{8}$ A carga tributária do país subiu em 2018 e alcançou o patamar de 33,58\% do PIB. Subiu 0,98\% entre 2017 e 2018, puxada especialmente pelo aumento do PIS/Confins (BRASIL, 2018).
}

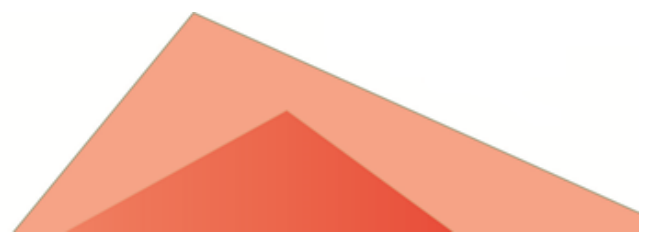


especialmente quando faltam recursos para os governos colocarem em prática políticas regionais de desenvolvimento.

A questão da "guerra físcal" está posta enquanto um dos elementos importantes da competitividade territorial. Mesmo com os estados e municípios ampliando suas participações em relação ao Produto Interno Bruto (PIB), eles, ao mesmo tempo, somaram, ao longo dos anos, responsabilidades funcionais e de gastos. A maior parte das receitas vai para o pagamento da dívida pública que, em 2018, somando estados e municípios, chegou ao montante de $\mathrm{R} \$ 1.051,97$ bilhão, com 70,2\% sendo de empréstimos e financiamentos internos e 11,4\% de empréstimos e financiamentos externos (BRASIL, 2018). ${ }^{9}$

Atualmente a capacidade de inversões dos diversos entes federativos é pequena. A dívida pública e a capacidade de atrair investimentos privados são baixas e se tornam um empecilho à geração de emprego e renda. Com isso, preferiu-se a atração de capitais privados por meio de renúncias fiscais ao invés de parcerias público-privadas adequadas e capazes de majorarem os investimentos. A solução está embasada tanto no acrescentamento da receita quanto nas diversas possibilidades de geração de emprego e renda por meio de investimentos produtivos - direcionados pelo Estado e capazes de diminuírem as desigualdades regionais - ao invés de simples distribuição da escassez entre entes federativos. Igualmente, por mais que seja necessária uma reforma tributária, ela não pode ser em prol do municipalismo e em detrimento da União, pois há soluções em que só a escala nacional é tributária. Para Vainer (2007, p. 12), o que “[...] falta é um pacto territorial democraticamente estabelecido que reconheça a autonomia dos estados e municípios, mas também, ao mesmo tempo, sua necessária solidariedade e complementariedade". Entretanto, um pacto territorial democraticamente construído, presente no campo das possibilidades, está ainda distante da realidade objetiva, uma realidade que ultimamente pouco condiciona mudanças estruturais de tal envergadura.

\footnotetext{
${ }^{9}$ Em suas relações com as instâncias subnacionais, o governo federal hoje praticamente se limita a exercer pressão para impor-lhe responsabilidade fiscal - leia-se a solidariedade forçada ao arrocho fiscal -, em perfeita consonância com as orientações do FMI, que sempre se preocupou em assegurar que o esforço fiscal não ficaria restrito à União e atingiria igualmente estados e municípios. Assim, apesar de receberem atribuições crescentes, as instâncias subnacionais foram conduzidas a aceitar uma renegociação de suas dívidas que comprometeu grande parte de suas parcas receitas (VAINER, 2007, p. $12-13)$.
}

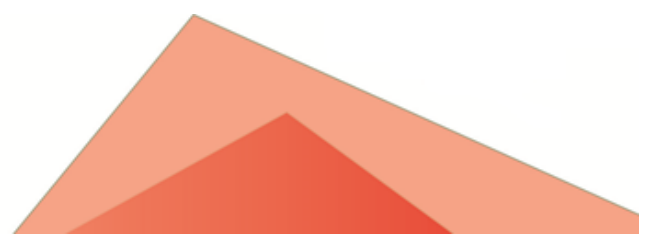




\section{CONSIDERAÇÕES: O PLANEJAMENTO TERRITORIAL E PROJETO NACIONAL}

A diminuição do papel do Estado keynesiano e o declínio da União Soviética (ambos os acontecimentos estão interligados) abriu uma brecha no campo intelectual que motivou o abandono da pauta "luta de classes" na escala internacional. Muitos foram seduzidos por falsas e despolitizadas agendas ambientais enquanto outros assumiram pautas extremistas identitárias, de desenvolvimento territorial e local. Centraram a atenção na desestruturação da União Soviética e, com isso, esqueceram-se da China, da Índia e de outros países asiáticos que passaram a apresentar destacável crescimento econômico. A União Soviética - a que mais contribuiu com os pressupostos do planejamento territorial - sucumbiu e o discurso do neoliberalismo que prega a diminuição do papel do Estado Nacional - tomou força. A questão posta, na época, passou a ser: "qual rumo as políticas de planejamento e desenvolvimento tomarão"? Vainer (2007) relata que Manuel Castells, na década de 1990, reconheceu a "falência histórica do estatismo" e afirmou que "nesse novo mundo, espaço unificado pela soberania do capitalismo globalizado, não restava aos lugares senão tentarem resistir ao desenvolvimento dos fluxos, e para dar eficácia a esta resistência deveriam recorrer ao planejamento estratégico" (VAINER, 2007, p. 13). As palavras-chave passam a ser "planejamento estratégico" e "desenvolvimento territorial e local".

Os planejadores incorporaram as visões empresariais e, com isso, passaram a impor aos territórios a mesma forma de administração que estavam conferindo os administradores às empresas. Com o "triunfo" do campo capitalista abriu-se a possibilidade a um vasto mercado global (por meio da diminuição das barreiras alfandegárias e pela incorporação dos países socialistas ao capitalismo) e, com isso, houve a necessidade das empresas adotarem uma lógica competitiva diferente das que adotavam as multinacionais. A década de 1980 foi, portanto, um marco temporal na teoria empresarial, especialmente formulada nas business schools. A concepção básica era a estratégia competitiva para transformar as grandes empresas em empresas globais (atuantes na maioria dos países), diante de um mundo aparentemente unipolar (e seus

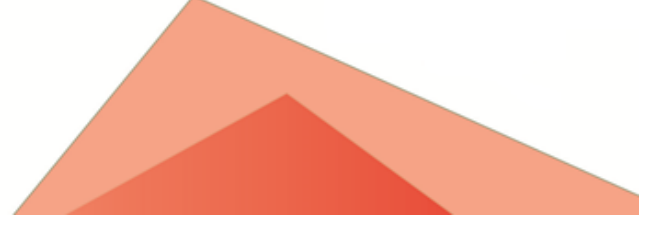


Estados múltiplos) e dominado pelos princípios neoliberais. Não demorou muito para que as convicções da competividade fossem transmutadas para o planejamento territorial e alcançassem as escolas de planejamento urbano e regional, administração pública, engenharias, economia e outras.

Passou a ser comum impregnar o território com os "instrumentos apropriados de batalha". Um destes aparelhos é a ampliação da fluidez das comunicações e da informação e, é obvio que, devido à participação de cada território na divisão do trabalho, os investimentos públicos são mais direcionados para o tipo de fluidez que irá atrair mais inversões, seja a ampliação da circulação das informações e/ou dos bens tangíveis. No Brasil, especialmente devido à sua posição na divisão internacional do trabalho, a fluidez necessária se baseia mais na implementação dos sistemas de transportes, armazenamento e logística. Quer dizer que para uns a vantagem competitiva está mais voltada às tecnologias informacionais e para outros são as de movimentação de mercadorias, como insumos, produtos e força de trabalho. O que muitos territórios barganham são suas infraestruturas, isenções/incentivos fiscais, custos e qualificação da mão de obra, bens e vantagens fundiárias, entre outros.

O discurso da inovação, da cooperação, do capital social, dos clusters ou arranjos produtivos territorializados, da solidariedade em rede, das redes de pequenos produtores independentes etc. aparecerem como livres e independentes do capital financeiro, dos oligopólios e oligopsônios e da crise fiscal. Aparentemente há um romantismo que remete a um modelo isolado. Por outro lado, pouco há de inovação e cooperação e o mais comum é uma exploração ampliada dos recursos humanos e ambientais. O que ocorre, na linguagem popular, é a entrega do "ouro ao bandido", camuflados nas discussões de market friendly planning (planejamento favorável ao mercado) e market oriented planning (planejamento orientado para o mercado). É claro que há exemplos de sucesso, como o conhecido caso da Terceira Itália. Mas temos que nos perguntar: a que custo? Em qual formação socioespacial esse modelo se insere? E qual a eficácia de transplantá-lo para outra formação econômica e social? Enfim, as respostas são difíceis, mas quase nenhum modelo mostrou-se positivo na história como ideal e reproduzível em outros espaços. Muito pelo contrário, cidades “ditas

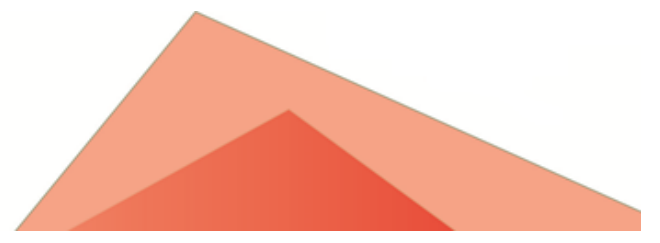


inteligentes" são exclusivistas e, até mesmo, xenofóbicas, mesmo as que tentam passar por mais tolerantes e diversificadas.

Rangel (2005) deixa claro que o Brasil passou por fases de desenvolvimento espontâneo, não premeditado, voltado às substituições de importações. Uma forma de desenvolvimento que era pouco entendida tanto por economistas quanto por administradores. Mas essa espontaneidade vai dando lugar a um esforço cada vez mais sistemático e consciente de ordenamento, graças ao Estado e, por meio dele, à sociedade brasileira, pelas suas forças politicamente mais representativas. Iniciou-se um esforço na direção do ordenamento que, em certos momentos, era proativo e em outros não. Mas, muitos acertos não foram intencionais. O Brasil demorou e, talvez ainda não faça plenamente, pelo menos de forma lúcida e correta, o planejamento entendido como ciência e arte, como " [...] rainhas de todas as artes e ciências do nosso tempo, porque é graças a elas que o enorme acervo de conhecimentos acumulado ao longo dos séculos ganha novo sentido, produzindo novos e surpreendentes resultados" (RANGEL, 2005, p. 453-454). O planejamento está presente, de modo mais ou menos organizado, desde Getúlio Vargas e, embora pareça não existir, na atual conjuntura, está presente em diversas escalas. Um malfazejo plano não deixa de ser um plano. A "desventura" também pode ser planejada. Por outro lado, um bom planejamento, uma planificação verdadeira, eficiente, só ocorrem, segundo Rangel (2005), em sociedades bem constituídas, cujos membros sejam capazes de comportar-se, em certa medida, como irmãos, são realmente capazes de programar ou planejar, porque não há planejamento sem transferências não compensadas de renda.

Se a nação é pré-condição para um plano bem-sucedido, como se justifica um planejamento local eficiente desprovido de qualquer relação com um projeto nacional de desenvolvimento? Como esses espaços locais, cada vez mais, se conectam a outros espaços globais, sem a intermediação da União (e do estado federativo), sem qualquer filtro institucional mais evidente, com ares de sucesso e altos níveis de competitividade? Na verdade, não há justificativas plausíveis. Pelo menos que abone ganhos na distribuição de emprego e renda territorialmente menos heterogêneos ao invés de uma maior polarização destes e expressos, cada vez mais, na estrutura da sociedade. Basicamente, as políticas locais são permeadas por políticas nacionais e dos 
estados subnacionais, servindo de filtros, mais ou menos favoráveis ao padrão pósmoderno que se chama "glocalização" (que trata da complexidade entre o local e o global). Todavia, pouco se fala da formação socioespacial e dos diversos filtros, em diversas escalas, que ela permite. O que implica dizer que os filtros das formações socioespaciais são significativos, pois perfazem uma totalidade, que é menos aparente, mas, em certo grau, percebível pelas grandes corporações. A questão é que os agentes locais assumem o papel de criação, de adaptação, de rearranjos culturais, políticos, institucionais, ideológicos, econômicos e outros, para extração de valor dos territórios pelas grandes corporações. A nação é, objetivamente, a estrutura que melhor satisfaz as precondições do planejamento, adquirindo assim nova e decisiva razão de ser.

Por isso tudo, não é adequado que o caminho de uma nação seja obra do acaso, quer dizer, ocorra sem planificação nacional, regional e local, ou seja, territoriais. Atualmente há elementos técnicos e científicos para acumulação, aumento da produtividade do trabalho, da distribuição de renda e, até mesmo, da preservação ambiental. É importante a criação de condições para que o país possa subordinar o intercâmbio, por meio da planificação, com o exterior aos interesses autarcizantes da sua construção interna. A soberania nacional - como um fato econômico, embasado na produção e na circulação de uma ampla cesta de insumos-produtos nacionais -, é importante e, somente através dela, com o planejamento do desenvolvimento, é que os espaços locais serão mais integrados e desenvolvidos ao invés de serem ilhas de prosperidade num vasto território de miséria. Essas ilhas de bonanças são falsas porque serviços públicos essenciais são responsabilidade da nação e, um pouco mais ou um pouco menos (fruto da complementação realizada pelos entes subnacionais), mantêm um certo padrão independentemente do território. A ideia é que autarcia passe e o plano fique. Todavia, acabados os governos nacional-desenvolvimentistas, os planos de governo substituem a planificação que, quase sempre, muda a cada mudança de governo. A autarcia passa e o plano passa com ela. Dominar e disciplinar (planejar) o intercâmbio básico de sua economia é possível somente com soberania. Só os Estados soberanos podem programar seu intercâmbio com o exterior, porque a soberania define a capacidade jurídica dos Estados, e só as pessoas juridicamente capazes podem contratar.

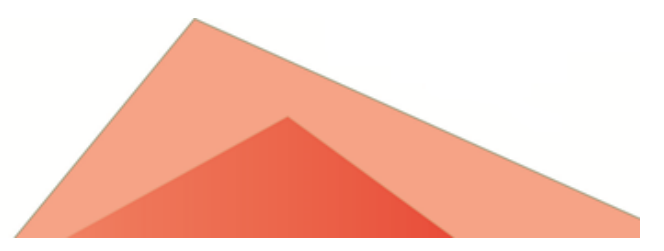


O progresso é assegurado pelo fato de que os interesses mais progressistas tendem a fortalecer-se e os mais retrógados a debilitar-se. Esse caminho, passivamente, leva a mudanças que não são abruptas ou puramente revolucionárias. O planejamento, portanto, é um instrumento que aprofunda, amplia e acelera essas transformações passivas. Até certa medida, a planificação facilita e instrumentaliza mudanças graduais que, ora ou outra, podem ser interrompidas por apostasias, por retrocessos, como vislumbramos no início da década de 1990 e a partir do ano de 2016. No passado a intervenção do Estado nos rumos da economia e da sociedade pareceu desconexa, sem passado, nem futuro, mas na verdade só expressava uma conexão e sequência histórica imanentes, porque respondia a uma exigência permanente da evolução da sociedade brasileira. O Plano de Metas, por exemplo, do governo de Juscelino Kubitschek, representou um grande passo, porque, pela primeira vez, de forma amplamente organizada, a nação foi confrontada com um esboço de plano realmente nacional. $\mathrm{O}$ desejo nacional de programação, que estava latente, tornou-se explícito, consciente, e este fato envolve um salto qualitativo (RANGEL, 2005).

Atualmente temos a mesma impressão, ou seja, tudo está desconexo e sem rumo. Porém, temos que lembrar que há mudanças significativas na ordem econômica, política e social mundial. Que há um processo de mudança de hegemonia global e que, no passado, esse tempo de mudança - de transição - também afetou o Brasil. Há muitas indefinições presentes, apesar das incertezas e descréditos, o futuro está no campo das possibilidades e a possibilidade, realizando-se, transforma-se em realidade, e é por isso que podemos definir a realidade como possibilidade já realizada e a possibilidade como realidade potencial (CHEPTULIN, 2004). Portanto, a história de uma nação não se resume ao tempo presente. O que está posto, na realidade, é um vazio de planos, de planificação. Mesmo que fossem postos em prática, os planos atuais são fragmentados e qualitativamente insignificantes, estão atualmente aquém das necessidades históricas do Brasil. O desmonte do Estado, na atualidade, é iminente, mas ainda não conclusivo. A crise que aflige a economia brasileira hoje é, sobretudo, uma crise de inteligência estratégica, e ela está consubstanciada no golpe de Estado de 2016, no governo de Michel Temer e especialmente no governo de Jair Bolsonaro. Reflete-se na crise

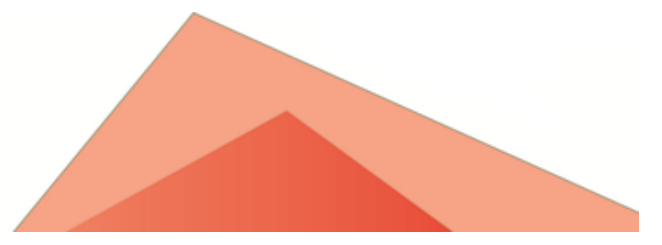


econômica de 2019 e na forma como o governo do Brasil está abordando os efeitos econômicos e sociais da pandemia do coronavírus (Covid-19).

\section{REFERÊNCIAS}

ALVES, A. J. F. S. Competitividade territorial. In: IV CONGRESSO PORTUGUÊS DE SOCIOLOGIA - MUNDOS SOCIAIS: SABERES E PRÁTICAS, Lisboa. Anais... Lisboa, n. 509, 2009, p. 1-23.

BRANDÃO, C. Mudanças produtivas e econômicas e reconfiguração territorial no Brasil no início do século XXI. Revista Brasileira de Estudos Urbanos e Regionais, São Paulo, v. 21, n. 2, p. 258-279, maio-ago. 2019.

BRASIL Ministério da Economia. Visão integrada das dívidas da União, dos Estados, do Distrito Federal e dos Municípios. Disponível em:

$<$ https://www.tesourotransparente.gov.br/historias/visao-integrada-das-dividas-dauniao-dos-estados-do-distrito-federal-e-dos-municipios\#anavigation>. Acesso em: 16 jan. 2020.

BRASIL. Receita Federal. Relatórios dos resultados da arrecadação. 2018.

Disponível em:

<http://receita.economia.gov.br/dados/receitadata/arrecadacao/relatorios-do-resultadoda-arrecadacao/arrecadacao-2018/2018-relatorios-do-resultado-da-arrecadacao-anosanteriores-capa?>. Acesso em: 22 nov. 2019.

CHEPTULIN, A. A dialética materialista: categorias da dialética. São Paulo: AlfaOmega, 2004.

CICIOTTI, E. Desenvolvimento e competitividade territorial. In: Programa de Desenvolvimento de Lideranças do Sistema Sebrae. Universidade Cooperativa Sebrae/Universidade Católica do Sacro Cuore Piacenza, Milão, s.d.

MELO, A. M. Crise federativa, guerra fiscal e "hobbesianismo municipal": efeitos perversos da descentralização? Revista São Paulo em Perspectiva, São Paulo, v. 10, n. 3, 1996, p. 11-20.

RANGEL, I. (1960). Obras escolhidas. Rio de Janeiro: Contraponto, 2005. v. 1 e 2.

SANTOS, M. O espaço dividido: os dois circuitos da economia urbana. São Paulo: EDUSP, 2008.

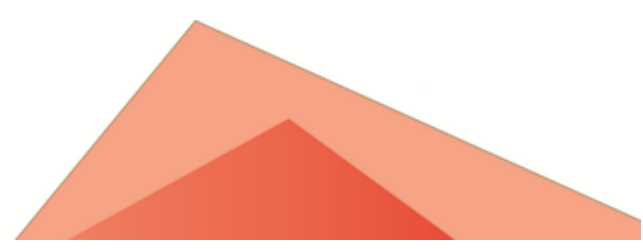


VAINER, C. B. Planejamento territorial e projeto nacional: os desafios da fragmentação. Revista Brasileira de Estudos Urbanos e Regionais, São Paulo, v. 9. n. 1, p. 09-23, maio 2007.

WOOD, E. M. O império do capital. Rio de Janeiro: Boitempo, 2014.

Recebido em março de 2020.

Aceito para publicação em abril de 2020. 